DOI https://doi.org/10.36059/978-966-397-213-8/32-66

\title{
PART 2. \\ THE STRUGGLE FOR THE NATIONAL IDEA PRESERVATION AS AN ELEMENT OF THE GREEK-CATHOLIC CHURCH ACTIVITY
}

It is a well-known fact that Ukrainian nation builds its national life on the geographical and cultural crossroads of the East and the West. This very proximity of both Western and Eastern civilizations, Christianity and Islam, Catholicism and Orthodox Christianity is to blame for the intricacies of the church and religion processes in Ukraine. Therefore, the people's national and cultural identity, as well as their religious traditions, were formed under the influence of both West and East. Still, as a famous Lviv dissident Ivan Gel' puts it, it is Europe that is responsible for the biggest impact on the ethnical culture of Ukraine as the latter has always been an integral part of the former ${ }^{95}$.

The long history of the Ukrainian Church witnessed several crucial events. They are the baptizing of the year 988, the Union of Brest in XVI century, undercover church activity and the revival of the Greek Catholic church in the second half of the XX century.

The event with the greatest importance was the baptizing of the Kyivan Rus', as the state managed to become fully Christian in the period of one-two generations lifetime. Still, there was strong evidence of Christianity present on the territory of the modern Ukraine long before baptizing, it is documented in the historical manuscripts, and it might have got to the country through the modern Transcarpathian region, which bordered on the Holy Roman Empire $^{96}$. Various historical sources testify to the spread of Christianity in the south of present-day Ukraine as far as the II century. In the "Zhytije sviatyh" («Lives of the Saints») there are repeated mentions about the Rus' Christians who lived in the VIII -

\footnotetext{
95 Гель І. Духовність України і спільний європейський дім. Украӥна. Наука i культура. Вип. 26-27. Київ: Знання, 1993. С. 132.

96 Пап Степан. Історія Закарпаття. Т. 1. Івано-Франківськ, 2001. С. 234-236.
} 
IX centuries; and in 839 there was the first mention of the bishops in Przemysl ${ }^{97}$. The existence of Christians among the Rus' people is also confirmed by the contract of Prince Igor with the Greeks in 944. His wife Olga was a Christian, who adopted Christianity during her official visit to Constantinople in 946, which was under the rule of the Emperor Constantine VII Porphyrogennetos ${ }^{98}$. Afterwards she invited German bishops and priests to come and preach in the Kyivan Rus'. According to the legend, Christian disciple Andrew the Apostle once visited the Kyiv Mountains and predicted the appearance of a large city with numerous temples ${ }^{99}$.

Having baptized Rus'-Ukraine in 988, Volodymyr the Great (Vladimir the Great), the Grand Duke of Kyiv, officially recognized Christianity as a state religion. The historian of the Ukrainian church, bishop Andrii Sapeliak states that with this act Volodymyr the Great created "the lasting Christian foundation for the unity of the Kyiv state, which exists in Eastern Europe, alongside the Roman-German Empire in the West and Byzantine in the South. The direct relations of Kyivan Rus' with Rome, which was the center of Christianity, also served as a guarantee of its independence, in a way"100.

Two prominent Slavic disciples, Saints Cyril and Methodius, made their important contribution to laying foundation of the Ukrainian Church; long before the baptism of the state took place both of them popularized Christianity on the western boundaries of the Kyivan Rus'. Their work was highly appreciated and supported by the Pope. The peculiarity of their missionary and scholarly work was that "the activity of the Saint Brothers Cyril and Methodius built a bridge between the West and Eastern Christianity" ${ }^{101}$. Thus, the main principle of the formation of the Cyril and Methodius culture, which is basically a combination of Byzantine and Roman

\footnotetext{
${ }^{97}$ Polska-Ukraina. 1000 lat sasiadstwa. T. 1. Przemyśl, 1990. S. 39-133; T. 3. 1996. S. 21-36.

98 Історія України / Заг. ред. В. Смолія. 3-є вид. Київ, 2002. С. 32-33.

99 Андрієнко О. 3 історії Української церкви. Київська старовина. 1992. № 1. C. 136 .

100 Сапеляк А. Київська церква на слов'янському Сході. Буенос-Айрес; Львів, 1999. С. 7.

${ }^{101}$ Полонська-Василенко Н. Історія України. Т. 1. Київ: Либідь, 1992. С. 94.
} 
ecclesiastical elements ${ }^{102}$, influenced Ukrainian Christianity from its onset. At the same time, the young Ukrainian Church clearly defined its identity as a part of the Ecumenical Church, it introduced the Slavic language into the church ceremonies, consequently, Slavic obtained the same level of importance as Greek and Latin, which clearly prevailed in the Christian world.

A well-known historian M. Chubaty, who dealt with the history of church, introduced the scientific concept of Ukrainian Christianity as a cross between Eastern Christianity and Western Christianity, formed on the basis of the pre-Christian culture of the Rus-Ukraine of the Dnieper region, he emphasized that as early as the end of the IX century it led to the creation of a clearly defined spiritual image of the Ukrainian nation with its individuality ${ }^{103}$. Strong political and ecclesiastical ties with Rome also contributed a lot to this process. The center of the Universal Church was visited by five embassies during the reign of Volodymyr the Great, later on this tradition found its continuation with his successors, especially during the rule of Yaroslav the Wise, who strengthened relations with the West by the means of dynastic marriages. The existing cult of St. Pope Clement, whose relics were transported to Kyiv, serves the clear evidence of the natural connection between the early Kyiv Christianity and Rome, which was the citadel of the European civilization back then.

After the collapse of the Roman Empire and the heyday of the Byzantine Empire, in 1054 there happened a split of the United Apostolic Church into Western Roman (Catholic) and Eastern Byzantine (Orthodox) ones. The hierarchs of Kyiv did not support the split because they had strained relations with Byzantium. Further actions of the Kyivan Rus' rulers proved they wanted to continue mutually beneficial relations with Western countries, those include an appeal of Grand Duke Iziaslav to Pope Gregory VII in 1073, keeping in touch with Pope Clement III on the part of the Kyiv Metropolitan Archbishop, developing relations with rulers of Germany, Poland, Hungary, England with the help of marriage ties, even though these

\footnotetext{
102 Паславський І. Берестейська Унія і українська християнська традиція. Львів: Місіонер, 1997. С. 8-9.

103 Чубатий М. Історія християнства на Руси-Україні. Т. 1. Рим; Нью-Йорк, 1965. C. 108.
} 
countries remained under the jurisdiction of Rome. The Ukrainian church of the period of Kyivan Rus' developed rather successfully, there were built grand temples in big cities, at the beginning of the XI century there existed 400 churches and 17 monasteries, with lots of them situated in Kyiv. It's worth noting that 600 churches burnt down in Kyiv in 1124 because of a massive fire, as it is written in the manuscript ${ }^{104}$.

Since the ancient period, churches were perceived as a centre of public and cultural as well as educational life. They had schools opened on their basis, and many monasteries were places where books were created and preserved. In the XIII century the Kyiv Metropolis (founded in 1037) ruled over 21 eparchies. After the Universal Church split into two, the Ukrainian Church tried to maintain neutrality - "it tried to be an equilibrium factor, the third party, a buffer between East and West, both of which tried hard to influence the Ukrainian position, it being the center of their regional interest"105. Byzantium side was particularly aggressive. It made attempts to limit the political, cultural, and ecclesiastical ties of Rus' with the West, and played its part in intrigues and strifes between the princes in order to weaken the Kyiv state and its church. Therefore Dmytro Stepovyk called it "Byzantine church imperialism"

After Kyivan Rus'-Ukraine lost its might, the Kingdom (Principality) of Galicia-Volhynia inherited its status and became the centre of ethno-political life, since its appearance on the geopolitical map of Europe in $1199^{107}$. The princes of Halych did their best to create the Metropolis of Halych and succeeded in 1302. Centered in Halych, it maintained close relations with Rome, which might be proved by the fact that Pope Innocent IV granted the royal title to Daniel of Galicia in 1253. This fact was of such a great importance

\footnotetext{
104 Полонська-Василенко Н. Історія України. Т. 1. Київ: Либідь, 1992. С. 236.

105 Сімкайло М., о. Берестейський собор і його значення. Берестейська Унія (1596-1996). Статті і матеріали. Львів: Логос, 1990. С. 75.

${ }^{106}$ Степовик Д. Множинність і єдність церкви. Київська Старовина. 1993. № 5. C. 10 .

107 Київська Русь: культура, традиції / Відп. ред. Я. Ісаєвич. Київ, 1982; Крип'якевич I. Галицько-Волинське князівство. Львів, 1999; Ісаєвич Я. Галицько-Волинська держава. Львів, 1999; Александрович В. Мистецтво Галицько-Волинської держави. Львів, 1999.
} 
that Mykhailo Hrushevsky stated "it was under Daniel's reign... that we got proclaimed a union with Rome" ${ }^{\text {"108 }}$.

For some time, Rome expressed full support to the Ukrainian Church and the state-building activities of the princes from GaliciaVolhynia. However, after the state had fallen victim to Polish expansion and annexation, Rome changed its church policy towards the Ukrainian lands dramatically and fully assisted to the Polish Catholicism promotion. At the beginning of the XV century, in 1414 despite the scarcity of Catholics living in the region there was created the Latin Metropolis in Lviv. It had to serve a single political purpose: to destroy the spiritual stronghold of the enslaved people ${ }^{109}$.

One could witness a serious decline of spirituality on the territory of Ukraine during the XIV - XVI centuries. After the Union of Lublin was signed in 1569, the Polish-Lithuanian Commonwealth got control over the Right Bank Ukraine. Still, it was Galicia region, which suffered the most under the Polish rule: its society was divided into higher and lower strata: the former one being flourishing Polish with its culture, language and Catholicism, while the latter one remained Ukrainian, where people still practiced Orthodox faith and used their national language. Naturally, there appeared certain contradictions between these strata, they were exacerbated by national and religious chauvinism, which revealed itself to the full scale during the Ukrainian Revolution of the XVII century, which happened shortly after ${ }^{110}$.

Thanks to the Jesuits influence, the Polish Catholic Church grew stronger and stronger. Their extensive missionary work was carried out by the orders of Dominicans, Bernardines, Franciscans in the XIII - XV centuries. They used to found Polish schools and spread Catholicism by all means available. The state policy of Poland was aimed at destruction of the Ukrainian Church, which remained the spiritual core of the Ukrainian nation.

\footnotetext{
108 Грушевський М. Історія України-Руси. Т. V. Київ, 1994. С. 508; Т. III. Київ, 1993. С. 69-73.

109 Панас Кость, о. Історія Української церкви. Львів, 1992. С. 44; Львів: історичні нариси. Львів, 1996. С. 521.

${ }^{110}$ Полонська-Василенко Н. Історія України. Т. 1. Київ: Либідь, 1992. С. 374.
} 
Another threat to the Ukrainian Church was posed by Moscow. After Constantinople had fallen in 1453, Moscow declared itself the heir to Byzantium and the "Third Rome". This became the state ideology under the reign of Ivan the Terrible, when Moscow was recognized as the capital, and after the government got united with the church. Under the pretenses of guardianship over the Orthodox believers and making an attempt to annex the Ukrainian lands, Moscow proclaimed Jon the Patriarch of Moscow and "All Great Russia", including Ukraine ${ }^{111}$.

Under these circumstances, the Ukrainian Church leaders concluded that the only way to preserve the church and the identity of the Ukrainian nation was to sign a union with the Roman Church and recognize the Holy See. In its time the First Council of Lyon in 1245, where some of the Ukrainian Church representatives were present, also served as an important milestone in the unification process. Archbishop Petro Akerovych informed the Apostolic Capital about the Tatar-Mongol invasion. The Second Council of Lyon declared the union between the Eastern and Western churches. This union was caused more by political than religious motives, therefore, it was fragile and non-lasting. Still, the leaders of the Kyiv Metropolis clearly understood that the union with Rome would be beneficial for the state, so they repeatedly tried to achieve it. The proof of this might be seen in the fact of participation of Metropolitan bishop Hryhoriy in defending the interests of the state, consistently argued for union with Rome. This was evidenced by the participation of Metropolitan Gregory in the Council of Constance in 1418, which was the first pan-European forum of the church and secular elite. In his speech, the Metropolitan bishop stated that the Ukrainian church was ready to recover the spiritual unity with the Holy See.

In 1439 Pope Eugene IV convened the Council of Florence in order to introduce the Union and the Ukrainian Church delegation (100 people), headed by Metropolitan bishop Isidore of Kyiv, played

111 Нагаєвський I., о. Католицька церква в минулому і сучасному України. Філадельфія, 1950. С. 27-28. 
a rather important role in $i^{112}$. The actions of Isidore contributed to the important decisions of the council, primarily it concerned the recognition of the Pope as the head of the Universal Church and the unification of the Western and Eastern churches. The union was signed by 115 bishops of the Latin Church.

Soon afterwards the Kyiv Metropolis returned from Moscow to its homeland, which strengthened the Kyiv-Halych Metropolis. According to the decision of the Union, the Eastern churches received the same status as Latin ones, and this fact significantly restricted processes of catholicization and polonization of Ukrainians. In 1458 Pope Pius IV appointed Gregory II of Kyiv the Metropolitan bishop, and he was in charge of the Ukrainian and Belorussian territories ${ }^{113}$.

The fate of the Ukrainian Church was heavily affected by the fall of Byzantine under the Turkish attack, and consequently the fall of the Patriarchal Center of Orthodoxy of Tsarhorod (Constantinople). Under the Turkish pressure, the Ecumenical Patriarch of Constantinople renounced his union and terminated relations with Rome. Both Lithuania and Poland also caused great damage to the national and religious life of Ukraine. Their Latin-Catholic circles refused to accept the Union, because it did not fit into the policy of spreading Catholicism among Ukrainians and Belarusians. They expected that the Union would become the instrument of Latinization of the Ukrainian Church. Their motto was "Whoever is not Latin Catholic is not a Christian". The Orthodox church was also constantly attacked by Protestants, not just by Latin Catholics. Some Ukrainian magnates, especially Konstantyn Ostrogski, who owned vast territories of Volyn and Galicia, came to the defense of the Ukrainian Church $^{114}$.

From the very start of their existence, religious fraternities contributed a lot to the preservation and development of the

\footnotetext{
112 Чубатий М. Історія християнства на Руси-Україні. Т. 2. Рим; Нью-Йорк, 1965. С. 164; Пашук А. Українська церква і незалежність України. Львів, 2003. C. 46-57.

113 Сапеляк А. Київська церква на слов'янському Сході. Буенос-Айрес; Львів, 1999. C. 15.

114 Сліпий Йосиф, митрополит. Історія Вселенської церкви на Україні. T. IV. Ч. 2. Рим, 1994. С. 29; Грушевський М. Історія України Руси. Т. V. С. 590-618.
} 
Ukrainian Church. They provided financial assistance to citizens, organized cultural and educational activities, and defended the church from the Latin-Catholic influence ${ }^{115}$. However, in the second half of the XVI century, fraternities increasingly extended their rights and started to interfere in the church activity: they wanted to have control of internal affairs, to have a say about the competence of bishops, to elect priests and bishops. They were seriously supported by the Patriarch Jeremias II of Constantinople who removed them from jurisdiction of bishops and subordinated them to himself in 1586, by means of granting the right of stauropegion. As a result, the church began to decline and the relations between the fraternities and the church hierarchy, which sought to get rid of dependence on secular structures, escalated. The contradiction between the Ukrainian Church and the Patriarch of Constantinople reached a threatening level. The hierarchs of the Orthodox Church fought against fraternities' policies. Bishop Hipatius Poceij, who became a Metropolitan bishop of Kyiv later as well as one of the creators of the Union, considered fraternities to be a pillar of the reformation movement, and he was right. He also believed that secular interference into the internal affairs of the church was heretical.

Comparing to the beneficial position of the Latin Catholic Church, the Ukrainian one was in a humiliating position, as it was secondary one and tried to develop without the state support. The decline of religious education had a negative impact on the intellectual and cultural level of the priesthood. The same result was provided by the practice of secular officials to interfere into the religious personnel problems. The Ecumenical Patriarchate of Constantinople did not really care about the state of affairs of the Ukrainian Church. Its interest was limited to the amount of money it received.

At the same time, the Moscow Church was gradually moving away from it, especially after the formation of its own patriarchate in 1589. It intensified its actions in cooperation with the current tsar in the aspect of expansion and strengthening of its influence on the Ukrainian Church. Still the Kyiv Metropolis tried to remain

115 Ісаєвич Я. Братства та їх роль в розвитку української культури XVI XVIII ст. Київ, 1966; його ж. Львівське успенське братство, його школа i друкарня. Львів: історичні нариси. Львів, 1996. С. 82-89. 
independent, as it was westward-leaning and considered cooperation with Rome its priority, with Rome being the center of the Universal Church. The Kyiv Metropolis refused to accept the Moscow Church's policy of state domination, autocephalous isolation, and rejected Constantinople's calls ${ }^{116}$.

Under these circumstances, the hierarchs of the Ukrainian Church, who had been in search of a radical solution to the urgent problems of the church for a long time, came to the conclusion about the possibility of a union with Rome. The main aim of the union was to get the Ukrainian church out of the deep crisis, and therefore save it as well as the identity of the Ukrainian nation. The intentions of the Ukrainian hierarchs were in perfect tune with the course, adopted during the Council of Florentine and met its conditions ${ }^{117}$. The fact that Hipatius Pociej joined the ranks of the Ukrainian bishops in 1593 was also an important contribution to the process of unification, as this person was a prominent church figure, writer and theologian, and later on his activity was closely connected with the Union of Brest in $1596^{118}$. Polish King Sigismund III was among the long-standing supporters of the union, he was clearly supported by the whole hierarchy of the Latin Church. The union initiative was fully approved not only by the Ukrainian bishops, but also by Pope Clement VIII, while he was informed about the state of the Ukrainian church and consequently was interested in its restoration, being an advocate of the ecumenical process.

At the same time, the union had many opponents. The Constantinople patriarch and other patriarchs of the East were the first to disapprove of it. After a meeting in Iasi in 1595, they sent a pastoral letter to the Ukrainian clergy of four believers in which they strongly disapproved of the intentions of Metropolitan bishop M. Rogoza and other bishops to unite with the Holy See and accused them of betrayal of the Orthodox Church. On the opposite side, there

116 Нагаєвський I., о. Католицька церква в минулому і сучасному України. Філадельфія, 1950. С. 41.

117 Паславський І. Берестейська Унія і українська християнська традиція. Львів: Місіонер, 1997. С. 37.

118 Паславський I. Іпатій Потій. До 450-річчя від дня народження. Ратуша. 1991. 28 вересня. 
were Catholic circles of Poland, who considered the union from a political-state point of view, and consequently they did not want to equalize the Ukrainian Church with Latin, and thus give Ukrainian the same rights Poles had ${ }^{119}$. Subsequently, a certain number of Ukrainian representatives could see through it and, as a result, ambitious K. Ostrogsky became an active opponent of the union, moreover he managed to persuade several bishops to join his side, including Bishop Gideon Balaban of Lviv, Mykhail Kopystensk of Przemysl, some influential representatives of nobility and clergymen who did not support the concept of a local church union ${ }^{120}$.

During the Synod of Brest in 1595, the initiators and creators of the union worked out and approved 33 articles on the conditions of the Ukrainian Church entry into the Holy See. The main conditions were as follows: the church retained the Eastern rite, its customs, the liturgical language; it preserved the right to elect bishops from among their candidates and their further ordination by a metropolitan bishop; it obtained the same equality as the Latin church in terms of taxation and privileges; Ukrainian bishops were to be granted seats in the Senate; Ukrainian nobility and city dwellers should have received equal rights with the followers of the Latin rite and should have been equally allowed to run for positions in city and state governments; it would be forbidden to force Orthodox faith followers into Catholicism, etc ${ }^{121}$.

On September 28, 1595, the Ukrainian delegation (23 people) left for Rome and arrived to the residence of Pope Clement VII on November 15, he met them two days later, and, having heard their statement on church unity, expressed the consent of the Holy See. On December 23, a solemn act of reunification or restoration of the union of the Ukrainian Church with the Ecumenical Church took place in the presence of 33 cardinals, the diplomatic corps of Europe,

119 Сапеляк А. Київська церква на слов'янському Сході. Буенос-Айрес; Львів, 1999. C. 28.

${ }^{120}$ Кметь В. Львівська єпархія: короткий огляд історії. Шематизм ЛьвівськоСокальської Української Православної церкви Київького Патріархату. 2000 рік. Львів, 2000. С. 17-19.

121 Завірач Василь, о. Флорентійський Вселенський Собор і Берестейська унія. Берестейська Унія (1596-1996). С. 65-66. 
and other representatives of the hierarchy. According to the Papal Bull of Pope Clement VII from February 23, 1596 the Ukrainian Church was defined as a local autocephaly in the union with Rome, and the document itself became the main canonical document of the Union of Brest.

Even before the Ukrainian ambassadors had left for Rome, the Pope had addressed the Polish King and the Senate, in his letters he had asked them to support the Uniate Church and grant Senate seats to its bishops, while the hierarchs of the Latin Church in Poland and influential politicians were to guarantee the exercise of equal rights for both churches ${ }^{122}$. Metropolitan bishop M. Rogoza received a letter, which instructed him to convene a meeting of Ukrainian bishops for the final settlement of the unification process, which had received full support in Rome ${ }^{123}$. The ratification of the Roman Act on the reunification of the Ukrainian Church with the Ecumenical church took place at the council held in the St. Nicholas Church in Brest (October 6-8, 1596), there were present Ukrainian as well as Polish bishops, papal delegates, royal ambassadors and priests ${ }^{124}$.

Simultaneously with the Union of Brest, there was held a different council headed by Prince K. Ostrogsky. He convened a meeting for the hierarchs of the Orthodox Church, including bishops from Lviv and Przemysl, nobility representatives and priests (about 200 people). Despite the king's objections and defying canonical dogmas, he declared that meeting to be a synod, and then the decision against the Union was made ${ }^{125}$. Still, actions of K. Ostrogsky could not stand in the way of ratification of the union and that's what happened during the Council of Brest with the support of majority of church followers and priests. Anyway, the determined struggle of K.Ostrogsky and his adherents hindered the development of the Ukrainian church, it led to appearance of the two opposite camps - the one of the supporters of the union and its opponents.

${ }^{122}$ Грушевський М. Історія України-Руси. Т. V. Київ, 1994. С. 596-603.

123 Сапеляк А. Київська церква на слов'янському Сході. Буенос-Айрес; Львів, 1999. C. 40.

${ }^{124}$ Грушевський М. Історія України -Руси. Т. V. Київ, 1994. С. 605-612.

125 Ibid. 
In these circumstances, the Ukrainian Church found itself in a difficult position immediately after the Union of Brest: The Orthodox camp considered it to be a traitor, and therefore an enemy, while the Polish Catholic church continued to treat it as secondary and, consequently, lower. On the positive side, having received the new canonical status and being in direct subordination to the Pope, the Ukrainian union church was to be respected by both camps, or at least taken into account. More than that, it was headed by prominent people, by Metropolitan bishop Hipatius Poceij (1599-1613) and Josyf Veliamyn Rutsky (1613-1637), both of them made a significant contribution to the establishment of the Union and the maintenance of the church in the first half of the XVII century. The latter one made considerable efforts to end the hostility of the Ukrainian Churches and it was during his reign, when the bold project of Meletius Smotrytsky was born - to create the Kyiv Patriarchate, which would unite the churches and be subject to the Pope, while maintaining full autonomy. Two attempts to unite the churches during the councils, first in Kyiv (1628) and then in Lviv (1629), failed mainly because of the resistance of the Cossacks. Metropolitan bishop of the Orthodox Church Peter Mohila (Petro Mohyla) (1631-1647) was among the supporters of the possible Kyiv Patriarchate under the patronage of the Pope, he regularly contacted with Rome, but he was strongly opposed by both the Cossacks and the Orthodox clergy, the latter one appeared to be increasingly Moscow-leaning ${ }^{126}$.

After the Pereyaslav Military-Political Agreement was signed between Bogdan Khmelnytsky and Moscow in 1654, in 1685 the Kyiv Orthodox Metropolis was subordinated to the Moscow Patriarchate by force. Soon afterwards, all the northern and western eparchies of the Ukrainian Catholic Church fell under the Moscow influence. Due to the looming threat on the side of aggressive Moscow church, in the early XVIII century all the remaining eparchies of Ukraine and Belarus, which had recognized the Pope's rule, united into the Kyiv Orthodox Catholic Church. This was how the paths of the two Ukrainian Orthodox Churches diverged. In

126 Панас Кость, о. Історія Української церкви. Львів, 1992. С. 77-78; Пашук А. Українська церква і незалежність України. С.94-106, 126; Кальницький М., Малаков Д., Юркова О. Нариси з історії Києва. Київ, 2002. С. 107-109. 
1720 an important synod in Zamosc was held, and it marked a crucial milestone in the history of the Ukrainian Church as it finally defined its face. As P. Isaiv put it «it basically reformed the Uniate Church (the Union church) as an independent church unit under the auspices of the Catholic church. The former Uniate Church, which had been kind of faceless, became the Greek-Catholic Church of the Ukrainian

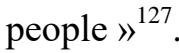

The Kyiv Metropolis was not the only one to go the difficult road to the union with Rome. At the same time, the Transcarpathian Eparchy faced similar difficulties. Despite the fact that Christianity appeared in this region earlier than in Kyiv, it was only at the end of the XIV century that the church was structured and taken into the care of the bishop of Przemysl, and in 1490 there was formed an eparchy subordinated to the Patriarchate of Constantinople. Under the influence of the Ukrainian Church, in the course of the Council of Uzhhorod in 1646, 400 priests (about half of the total amount of them in the region) decided to accept the union with Rome. Still, it was only in 1721, that the rest of the Orthodox clergy joined them. Thus, at the beginning of XVIII century, the Ukrainian Greek Catholic Church united all the eparchies of the western lands and the Right Bank of Ukraine ${ }^{128}$.

The majority of church and national history researchers believe that the Union of Brest comes second in the significance of the events in the history of Ukraine and Ukrainian Christianity, right after the Baptism in 988. The factors taken into account are the positive outcome for Ukraine, a natural result of objective processes in the historical development of the church, the context of the integration process of the Eastern and Western traditions. Metropolitan bishop Josyf Slipyj, a prominent constructor and historian of the Ukrainian Church, highly appreciated the Union of Brest. He emphasized its great importance for the revival and renaissance of the Ukrainian Church, and stated that the union had become an effective means of forming the Ukrainian people as a separate nation ${ }^{129}$. The Union of

127 Ісаїв П. Історія церкви. Енциклопедія украӥнознавства. Загальна частина. Т. 2. Київ, 1995. С. 613.

${ }^{128}$ Ibid. C. 616; Пашук А. Українська церква і незалежність України. С. 138-188.

129 Сліпий Йосиф, митрополит. Історія ... С. 30-113. 
Brest was certainly successful, if one takes into account its consequences, because as the modern historian Dmytro Stepovyk put it, it "corresponded to the general integration process, the interests of the Ukrainian people" 130 .

An important consequence of the Union of Brest was the upraise of one of the oldest monk orders - the Order of St. Basil the Great in Ukraine. Monasteries of this order led quite hermit lives, were subject to local bishops and played a small role in the social and church life of the region. After the union, Metropolitan Bishop Yosyf Rutsky united the monasteries, made them independent from bishops, put an archimandrite to head them, founded novitiates, developed theology and philosophy studies. The Metropolis of Kyiv was assisted by the Holy See, which approved all the measures taken. With the permission of Pope Paul V, since 1615 monasteries became the basis for new schools and colleges for Ukrainian youth to be established. The Basilians launched a network of printing houses, in particular in the cities of Suprasli, Univ, Uhertsi, and later on in Pochaiv, Lviv, Zhovkva $^{131}$. In the middle of the XVIII century, the OSBM Congregation in Ukraine united 130 monasteries and some 700 Basilian monks. The division of Poland in 1772 dealt a heavy blow to the Basilian Order and disrupted its structure in Ukraine. Monasteries that remained on the territory that Russia received were liquidated, and in 1839 there had been 190 of them, monasteries of the Kholmshchyna region were an exception, where they were destroyed in 25 years ${ }^{132}$.

At the end of the XVIII century, the once mighty Polish state was in a deep crisis. Taking advantage of the favorable geopolitical situation, neighbouring Russia, Austria and Prussia made three divisions of the Commonwealth of Poland in between 1772-1795 and erased from the map of Europe as a state. As a result of these events,

${ }^{130}$ Степовик Д. Множинність і єдність церкви. Київська старовина. 1993. № 5. C. 12 .

131 Ісаєвич Я. Українське книговидання: витоки, розвиток, проблеми. Львів, 2002. С. 276-285.

132 Стоколос Н. Українська церква у контексті конфесійних трансформацій на Правобережній Україні під владою Російської імперії. Украӥнський історичний журнал. 2002. № 4. С. 94-109. 
the Carpathian Terrain was incorporated into the Austrian Empire. Of all the new lands, Galicia was the largest and most neglected province ${ }^{133}$.

It was clear that Ukrainian Galicia (which constitute $71 \%$ of the population of 2 million people in total in 1773) in the hope of the best life welcomed the transition of power to Habsburgs, who were known as monarchs who sought to adapt the absolute monarchy to market relations and new trends in social and political life. The imperial reforms of Maria Theresa, Joseph II, Franz I reformed agrarian relations and triggered the cultural and educational awakening of Ukrainians. Still, in the lives of the churches there was a major change introduced, from that time on they were subordinate to the state. In 1784, in the former Dominican monastery in Lviv there was established a Greek Catholic seminary, the same year there were created Faculties of Philosophy and Theology in the Emperor Franz University of Lviv. Also there were issued special decrees in order to equate Ukrainian priests in rights and privileges with their Latin counterparts, education in Ukrainian language was allowed in schools $^{134}$.

The restoration of the Metropolis of Halych became a significant event in the ecclesiastical and religious life of the region and for the church in general. After the division of the Commonwealth, the outpost of the Kyiv Metropolis was on the territory belonging to the Russian Empire. Therefore, the bishops of Halych and Chelm had an idea to transfer the metropolis centre to the reconstructed city of Lviv, which had just broken through the medieval walls in order to become the center of dynamic events of a new historical era. Galician hierarchs repeatedly appealed to the emperor, especially after 1803, when Polish priests launched a campaign in order to subordinate Ukrainian eparchies to the Latin rule. However, it was only in 1808 when they received the Bull of Pope Pius VII and the emperor's permission to restore the Halych Metropolis in the largest

\footnotetext{
133 Верига В. Нариси історії України (кінець XVIII - початок XX ст.). Львів: Світ, 1996. С. 145.

134 Великий А. Г., ЧСВВ. 3 літопису християнської України. Т. VIII: XIX ст. Рим: Вид-во оо. Василіян, 1976. С. 48-49; Історія України. Львів: Світ, 1996. С. 159 .
} 
city of the region, in Lviv. The church was headed by Antin Anhelovich (1756-1814). The re-built archdiocese included Przemysl-Sambir-Sianotska, Kholm-Bielsk and Lviv-GaliciaKamenets eparchies ${ }^{135}$.

The Napoleonic wars and the Congress of Vienna in 1815 halted to a stop the implementation of the Austrian reforms concerning Galicia. Still, Metropolitan bishop Antin Anhelovich managed to resolve a number of issues that contributed to the spiritual and cultural progress of the country and to the organizational strengthening of the church. The Metropolitan bishop help to lay the foundation of the Teachers' Institute in Przemysl, defended the Orthodox calendar from changes in its system of holidays, and defended the right to receive education in a native language in the system of official teaching.

A particularly large-scale cultural and educational campaign was launched by Mykhailo Levytsky (1774-1858), first the Bishop of Przemysl, and then Metropolitan Bishop of Lviv in $1815-1858^{136}$. He also launched the building of schools, this was approved by the Przemysl synod, which decided there was an urgent need to restore the parish schools having been destroyed by the wars and to introduce Ukrainian into them. The Metropolitan bishop also succeeded in introducing a new statute for Austrian schools in Galicia. As a result, in the period between 1816 and 1819 there were 383 new parochial schools established in the province ${ }^{137}$. As a person responsible for the school and its development, M. Levytsky appointed a talented organizer and defender of the mother tongue of the priest Ivan Mohylnytsky, who had created the statute of the Przemysl Teachers' Institute. His initiative was also defining in the decision to establish a cultural-educational "Society of Galician Greek Catholic Priests for the Propagation of Enlightenment and Culture among the Faithful" in

135 Федорів Юрій, о. Історія церкви в Україні. Торонто, 1967. С. 258-259; Ададуров В. Львів у наполеонівську епоху. Львів: місто - суспільство культура : Збірник наук. праць / За ред. М. Мудрого. Львів: ЛДУ ім. І. Франка, 1999. C. 209.

136 Сапеляк Андрій, владика. Київська церква на слов'янському Сході. БуеносАйрес; Львів, 1999. С. 101.

137 Петрів І. Митрополит Михайло Левицький - перший кардинал-українець. Берестейська Унія (1596-1996). Статті і матеріали. Львів: Логос, 1996. С. 187. 
1816 in Przemysl, the task of this organization was to publish and distribute spiritual literature in the Ukrainian language. The same year, they printed "Bukvar" ("The ABC"), shortly afterwards Reverand I. Mohylnytsky compiled a grammar of the Ukrainian language. Later, in 1839, M. Levytsky, the first cardinal, who was Ukrainian by nationality, voiced the protest against the liquidation of the union by the Russian government on the Right Bank, Volyn and Belarus.

The next Bishop of Przemysl Ivan Snigursky continued to address problems of civil patriotism and enlightenment. Thanks to his persistent activity in 1832,411 public schools were operating in the eparchy ${ }^{138}$. In the 1820 s - 1830s, the young bishop I. Snigursky surrounded himself with a group of patriotic priests and intellectuals, who organized editions of books in Church Slavonic in Przemysl Greek Catholic printing house. As the result of their activity there appeared several books: "The Wedding of Rus"” by Josyf Lozynsky (1835), "The Alphabet and the Latin alphabet" ("Abetka i abetsadlo") by Markian Shashkevych ${ }^{139}$. I. Snigursky sought to create a number of new eparchial structures and a network of elementary schools in Nadsiannia $^{140}$.

Since 1815, the Metropolitan Greek Catholic Consistory launched a broad campaign to promote Ukrainian in schools. Because of the lack of teachers, Metropolitan bishop Mykhailo Levytsky gave the task to the parish priests to implement these activities. Still, the problem was that the Polish and Austrian authorities obstructed development and spread of Ukrainian Cyrillic writing because they did not consider the Rusyn language to be equal to Polish. Publicist speeches of Galician scholars, especially representatives of the Greek Catholic clergy, were of great importance for the formation of

\footnotetext{
138 Ясіновський Ю. Дяко-учительський інститут у Перемишлі. Перемишль $i$ Перемиська земля протягом віків. Перемишль; Львів, 2003. С. 249-259.

139 Перемишль і Перемиська земля протягом віків. Вип. 3. Перемишль; Львів, 2003. С. 22-23.

140 Лірвак 3-над Сяну: Перемиські друки середини ХІХ століття / Упор. В. Пилипович. Перемишль, 2001. 451 с.; Дух і ревність. Владика Снігурський та інші перемишляни / Упор. В. Пилипович. Перемишль; Львів, 2002. 498 с.
} 
national character and its identity, as well as protection of the mother tongue $^{141}$.

Despite his spiritual opponents efforts, Metropolitan bishop M. Levytsky issued three memorials (1817, 1821, 1830), concerning the "independence of the Ukrainian language". The Greek Catholic deans were supposed to supervise Ukrainian schools. Ukrainians also sought for the replacement of Roman Catholic chaplains in six Ukrainian schools in the region by Uniates (union priests) ${ }^{142}$.

The long-standing Polish domination deteriorated not only the Ukrainian language, historical memory, customary law, but also the intellectuals of the enslaved people. In the XIX century, according to the Ukrainian adversaries, there remained only "hlop and pip" (a common worker and a clergyman) in the Ukrainian province. Therefore, one these social strata gave a start to the national, cultural and political revival and this was a characteristic feature of the process $^{143}$. Consequently, it is only natural that priests were on the forefront of the national and cultural revival, as they were people with certain social status and had trust of the peasantry ${ }^{144}$.

A new stage of Ukrainian revival in Galicia was started in the 1830's by a group of young theologians, the "Ruska Trijtsia" (Rus' Trinity). Their activity aimed at protection of their national language was increasingly resembling the national liberation struggle. The "Ruska Trijtsia" actively promoted their mother tongue, considering it to be the main feature of the identity for people. In 1833, they compiled the first collection of works in the vernacular language (in the spoken language), it was called "Syn Rusi" ("The Son of Rus""), but it was banned from publication for ideological reasons. Their next collection "Zoria" ("The Morning Star") (1834) also was not published due to the censorship of a political nature, in particular because of M. Shashkevich's poems in which he called out to people

141 Великий А. Г., ЧСВВ. 3 літопису християнської України. Т. VIII: XIX ст. Рим: Вид-во оо. Василіян, 1976. С. 102-104, 105.

142 «Русалка Дністрова»: Документи і матеріали / Упор. Ф. І. Стеблій та ін. Київ: Наук. думка, 1989. С. 243-244.

143 Великий А. Г., ЧСВВ. 3 літопису християнської України. Т. VIII: ХІХ ст. Рим: Вид-во оо. Василіян, 1976. С. 113.

${ }^{144}$ Ibid. C. 113-114. 
to fight for their rights. Finally, in 1837, they managed to publish an almanac in spoken Ukrainian in the printing house of the Royal Hungarian University (Buda), it was called "Rusalka Dnistrova" ("The Nymph of Dniester") and had more than 200 copies $^{145}$.

The almanac "Rusalka Dnistrova" («The Nymph of Dniester») brought recognition to its publishers among the Slavic community and was highly appraised by the nationally active part of Galician society ${ }^{146}$. It is clear that the reaction of the Austrian authorities and the Polish administration in Galicia was totally opposite. The collection was confiscated and almost completely destroyed according to the special order of the Galician governor ${ }^{147}$.

Representatives of the Transcarpathian clergy also showed interest in the ethno-national heritage. In particular, the monk of the Mukachevo monastery, Ioannykij Bazylovych, wrote the first scientific history of Transcarpathia - "A Short Sketch on the Foundation of Fedir (Fyodor) Koriatovych" (Kosice, 1799-1805), in which he substantiated the authenticity and identity of the local Ruthenians as an integral element of the Slavic part. Subsequently in 1830, the famous ecclesiastical activist Mykhailo Luchkai published his "Grammar of the Slavic-Rus' Language" in the city of Buda and shortly afterwards (1843) there appeared a six-volume "History of the Carpathian Ruthenians". Works of Transcarpathian authors were also published in the cities of Przemysl, Lviv, and Kolomyia ${ }^{148}$.

In 1848, the whole of Europe was ignited by the revolutionary movement, which became known as the "spring of the nations". The Austrian Empire had its most extreme case and therefore experienced several groundbreaking changes. The new Austrian government declared democratic freedoms of conscience and religion, freedoms of the press, assembly, organizations. On April 17, Emperor Ferdinand I signed a law to abolish serfdom, to free peasants from

145 «Русалка Дністрова»: Документи і матеріали. С. 75, 98; Шашкевичіана. Збірник наукових праць. Вип. 1-2. Львів; Броди; Вінніпег: Просвіта, 1996. С. 230.

146 Демкович-Добрянський М. Українсько-польські стосунки у XIX сторіччі. Мюнхен, 1969. С. 23.

147 Центральний державний історичний архів України у м. Львові (далі ЦДІАУЛ). Ф. 146. Оп. 7. Спр. 2772. Арк. 123-124.

148 Пап С. Історія Закарпаття. Т. 3. Івано-Франківськ, 2003. С. 140-151. 
duty, and to grant them liberty; on April 25, 1848 there was a proclamation of the constitution and declaration of the start of general elections to parliament, it was also allowed to form the National Guard. This revolution triggered democratic transformations and therefore led to the unprecedented rise of the national movement in Galicia, giving it its political character. Struggling with the Polish separatism, the Austrian government, in particular the governor of Galicia, Count F. Stadion, was forced to treat the Galician Ruthenians (this was how local Ukrainians called themselves then) well, as they were still loyal to Vienna and stated their modest demands in the petition to the Emperor. This petition was dated April 19 and the delegation was headed by Mykhail Kuzemsky, a wingman. The demands were moderate indeed: to introduce the Ukrainian language in schools, to issue state orders in the Ukrainian language, to allow Ukrainians to run for positions in the self-governing bodies, to guarantee equal rights and privileges to the Greek Catholic clergy in comparison to the Latin ones ${ }^{149}$.

The course of social and political events in Galicia clearly demonstrated the desire of the Ukrainian Church to participate in the national movement. At that time, the church underwent transformation from a spiritual force into a social institution ${ }^{150}$. It should be taken into account that the contemporaries of the events treated the cultural and political uprising of Galicia, recognition of its Ukrainian essence, as well as the rapid rise of the national liberation movement during the revolutionary events of 1848 quite differently, especially in the context of the Ukrainian geopolitical position in between the West and the East, therefore their ambiguous views resulted in different directions of church policy ${ }^{151}$. At that time, the clergymen became almost the only mediator and representative of the population in their relations with the state authorities.

\footnotetext{
149 Головна Руська Рада. 1848-1851. Протоколи засідань і книга кореспонденції / За ред. О. Турія. Львів, 2002. С. Х-ХХХІІ; Великий А. Г., ЧСВВ. 3 літопису християнської України. Т. VIII: ХІХ ст. Рим: Вид-во оо. Василіян, 1976. C. 114-115.

150 «Русалка Дністрова»: Документи і матеріали. С. 247-251.

151 Турій О. Конфесійно-обрядовий чинник у національній ідентифікації українців Галичини в середині XIX століття. Записки НТШ. Т. CCXXXIII. Львів: НТШ, 1997. С. 75.
} 
Thus, it is quite natural that the Supreme Ruthenian Council (SRC), the first Ukrainian political organization in Galicia, established on May 2, 1848, was headed by the authoritative Bishop of Brest Hryhoriy Yakhimovych (1792-1863), and his vice was Miykhailo Kuzemsky (1809-1879), also a canonic clergyman, and the secretary was the experienced reverand, Mykhailo Malynovskyi (1812-1894). The majority of Council members were people related to church. In its manifesto to people, the leadership of the SRC declared the unity of a 15 million (Ukrainian) "great Ruthenian people" who "spoke the same language" and had a powerful state in the past. The main directions of the program of the organization included preservation of the Greek Catholic faith and rite as well as granting the church the same rights as other churches had, democratization of public education and implementation of the native language in all state and public institutions, fighting for and defense of the constitutional rights and freedoms of the people ${ }^{152}$. The first Ukrainian magazine "Zorya Halytska" («The Star of Halych») became the spiritual body of the Council. There were rural, school, financial and other departments under the Council. In the districts and dean's offices, they formed 50 so-called "smaller" (deanal) councils, which were led by clergy representatives. In July 1848, district councils began to appear in the cities of Berezhany, Zhovkva, Kolomyia ${ }^{153}$.

The Galician clergymen actively participated in the first elections to the Austrian Parliament in 1848. During the election campaign, the Supreme Ruthenian Council relied mainly on their priests. In the end, even though, as the result of the election, Ukrainians managed to get only 39 (including 27 peasants and 9 clergy) seats out of the 96 mandates given to Galicia, this was a certain achievement, because from that time on they could use the parliament to be heard and representatives to solve their problems. The Ukrainian Parliamentary

152 Великий А. Г., ЧСВВ. 3 літопису християнської України. Т. VIII: XIX ст. Рим: Вид-во оо. Василіян, 1976. С. 118; Верига В. Нариси історії України (кінець XVIII - початок XX ст.). Львів: Світ, 1996. С. 167; Зоря Галицьька. 1848. 15 травня.

${ }^{153}$ Головна Руська Рада. 1848-1851. С. XXIV-XXV. 
Club was formed and headed by Bishop Hryhoriy Yakhymovych ${ }^{154}$. Under his leadership, Ukrainian ambassadors created four memorials on national relations in the province, as well as a petition with 15,000 signatures on the issue of division of Galicia into Ukrainian (Eastern) and Polish (Western). The proposal was to have a different governor in Eastern Galicia, and on the territory of the region Ukrainian would be introduced in institutions, schools, temples, while Galician Ukrainians were to be given positions in state authorities. Although the emperor and his government generally acknowledged the general validity of the Ukrainian project, they did not dare to implement it because of Poles.

One of the most prominent events that took place in the course of "the Spring of Nations" was the first Prague Slavic Congress, which was convened in Austria in June 1848 and during which, according to the aims of its organizers, they were to formulate the principles of the Austrian Slavs' interaction - to secure their national rights, to oppose German centralism and to transform the Habsburg Empire into a federal association. The Galician delegation, led by priest Hryhoriy Hynylevych (1809-1871), highlighted the problem of the division of Halychyna (Galicia), stressed on the importance of introduction of the Ukrainian language, and emphasized the ethnic equality of Ukrainians among other peoples. In October 1848, despite the disapproval of the Austrian administration of Galicia, the Supreme Ruthenian Council convened a "congress (meeting) of Ruthenian scientists" in Lviv. It was attended by 119 representatives of the Galician intelligentsia (about $90 \%$ of them were priests under the patronage of M. Kuzemskyi). The congress passes an important decision, they decided to establish the first scientific society "Ruthenian Matytsia" in Lviv. The statutory task of this organization was to publish and spread "good and useful books for strengthening of faith and morality, spreading knowledge, development of eloquence, calligraphy, technology, economy and pedagogy"155.

\footnotetext{
${ }^{154}$ Мудрий Софрон, о. Нарис історії церкви в Україні. Рим; Львів: Вид-во оо. Василіян, 1995. С. 311.

${ }^{155}$ Великий А. Г., ЧСВВ. 3 літопису християнської України. Т. VIII: XIX ст. Рим: Вид-во оо. Василіян, 1976. С. 119; Сухий О. Від русофільства до
} 
It is also worth mentioning that the Supreme Ruthenian Council managed to get back some of the national symbols: the blue-yellow flag, which is the flag of modern Ukraine, and the coat of arms of the Halych-Volyn princes - a golden lion against a blue background; also they founded a prominent institution for conducting cultural and educational work in Lviv - Narodny Dim (a communal hall), which operated until $1939^{156}$.

In connection to the above-mentioned events, it is worth to mention activity of the conscious compatriot Vasyl Podolynskyi, who was the Lemko priest from the village Vetlyny, but who tried to contribute to the creation of the Ukrainian state. In the summer of the same year he published a book "The Word of Precaution" (in Polish), in which he detailed the future national-state concept of the region's development. Considering the four perspectives of the future of Galicia (as a part of Austria or Poland, or Russia, as an independent state), the author came to the conclusion that the only change for his shattered people to preserve their nation was to have a united independent Ukrainian state, which should include Galicia. Other ways brought national destruction ${ }^{157}$.

Unfortunately, as early as the beginning of 1850's, the reactionary regime gained its powers back in Austria, and consequently set out to return to absolutism. The constitutional rights of Ukrainians were abolished. The post of governor of Galicia was taken by Count A. Golukhovsky and his entry into office meant strengthening pressure on the Greek Catholic Church and leaders of the SRC. The latter one was forced to dissolve on June 30, 1851. The omnipotent Polish administration ignored the draft of the governmental decree about the division of Galicia into Ukrainian and Polish ones. The Ukrainian language was gradually ousted from schools. All these facts led to the spread and popularization of Russophilism ("Moscowphilism") primarily as a protest against the increase of the forced Polish and Latin influence on Ukrainians. On the other side, Russia

\footnotetext{
москвофільства. Російський чинник у громадській думці та суспільнополітичному житті галицьких українців у XIX столітті. Львів, 2003. С. 250-311. ${ }^{156}$ Галицькі митрополити. Біографічний довідник. Львів: Логос, 1992. С. 32. 157 Франко І. Панщина та їі скасування 1848 р. в Галичині. Франко I. Зібрання творів. Т. 47. Київ, 1986. С. 122.
} 
was pursuing its own goals, that's why it supported this trend not only morally but also financially ${ }^{158}$. During this difficult period, responsibilities of the patriotic clergy increased. In 1856, Mykhailo Levytsky (1774-1858) received the title of Cardinal from Pope Pius IX. He was the first among the Galician metropolitan bishops to be promoted, and that led to certain uplifting of the reputation of the Greek Catholic Church and its influence on the solutions of some national-religious problems of Western Ukrainians.

After the defeat of Austria in the war with Piedmont (1859) and the threat of a new national liberation movement in the empire, Austrian government was forced to return to the constitution of 1860 , which was somewhat liberalized the following year. Using the defeat of Austria in its war against Prussia, the Hungarians gained the same status as Austrians and their own parliament. Subsequently, in 1867, the Austrian-Hungarian Empire was formed ${ }^{159}$. Austria saved its influence on 17 crown lands, including Galicia and Bukovina; its constitution and laws proclaimed the equality of all peoples of the empire, as well as the right to preserve and use their mother tongue in schools and public institutions. Still, in reality, Ukrainians did not get the declared rights. That is why the Ukrainian representatives and ambassadors in the Vienna Parliament and in the Diet of Galicia and Lodomeria fought hard for the realization of civil rights. An important role in this struggle belonged to Hryhoriy Yakhymovych, who headed the Metropolis of Halych in 1860 and tried to support the ambassador priests in every way possible.

The elections to the Diet of Galicia and Lodomeria reflected the real social influence of the Greek Catholic clergy, which had to be drawn into political battles, as there was no other social force capable of taking the political lead in Ukrainian society at that time. At the beginning of 1861 the bishop of the Greek Catholic Church addressed the clergy and religious followers with a vast explanation of the essence of the elections and tasks of the elected representatives in the local parliament. He appealed to their wise choice of "sensible, intelligent, religious, conscientious men who had a distinct

158 Нариси з історії суспільних рухів та політичних партій в Україні (XIX ХХ ст.). Львів: Світ, 2001. С. 18-19.

${ }^{159}$ Цьольнер Е. Історія Австрії. Львів, 2001. С. 399-409. 
commitment to our Ruthenian cause" ${ }^{\$ 60}$. However, having learned their bitter lesson in 1848 , the clergy tried to secure their own proper representation in the elected bodies of state power. Therefore, among the 77 candidates proposed by the Ruthenian election committee headed by H. Kuzemsky, who was originally from Krylos, there were 58 priests, 19 representatives of the secular intelligentsia and no peasants. Yet the election results brought disappointment to the clergy: among the elected people there were only 22 priests, 8 representatives of the secular intelligentsia and 16 peasants, who received ambassadorial rights ${ }^{161}$. Reverand Volodymyr Terletsky blamed it on the Polish nobility, he claimed they discouraged peasants from voting for their pastors, and that fact accounted for the poor representation of the clergy in the outcome of the election ${ }^{162}$. However, the working processes of the Diet of Galicia and Lodomyria proved there were basic differences between the positions of the clergy and the peasantry in socio-economic issues, especially when they discussed the problem of eliminating the natural and monetary tributes of the parishioners in favor of priests, and an issue of regulating the payment for the rites ${ }^{163}$.

Among the ambassadors to the State Council in Vienna, there was Reverend Ivan Ozarkevych (father of the writer Natalia Kobrynska) who consistently defended the interests of voters since 1873 . Out of the 16 Ukrainian ambassadors of that time, 11 people were priests. I. Ozarkevych became the leader of the Galician deputation, which reported to the emperor on the arbitrariness of local authorities on December $12,1895^{164}$. Shortly afterwards, in 1908 , there were elected

\footnotetext{
160 Турій О. «Попи і хлопи»: Соціальна «доктрина» греко-католицького духовенства i національно-політична мобілізація українського селянства Галичини в середині ХІХ століття. Ковчег. Ч. 3. Львів, 2001. С. 314-315.

161 Ibid. C. 316-317; Чорновол I. Українська фракція Галицького краєвого сейму 1861-1901. Нарис з історії українського парламентаризму. Львів, 2002. С. 82-135.

162 Терлецький В. И наше слово о виборах и сойм. Слово. 1861. 11 травня.

163 Турій О. Соціальний статус і матеріальне становище греко-католицького духовенства Галичини в середині ХІХ ст. Ковчег. Ч. 2. Львів, 2000. С. 115-118.

164 Королько А. Культурно-просвітницька і громадсько-політична діяльність о. Івана Озаркевича (1826-1903) в контексті українського національного відродження. Питання історії України. Чернівці: Технодрук, 2013. Т. 16. C. 37-44.
} 
the following people to the Vienna parliament from the National Democratic Party: priests Josyf Folysa (Lviv district), Stepan Onyshkiewicz (Sudova Vyshnia, Sambor) and Tyt Voinarovsky (Kolomyia district), who divided 30000 morgens of land among the farmers of Pokuttya ${ }^{165}$.

Activity of the Metropolitan bishop H. Yakhymovych started from a series of protest statements to the emperor with the following demands: to introduce the spoken Ukrainian language in schools with the majority of Ukrainian learners, to teach it in secondary schools, to implement its usage in administrative bodies and public institutions; to make fluency in Ukrainian an obligatory criterium while filling in government positions. Responding to these statements, the government agreed to grant free usage of the Ukrainian language in Galicia, and agreed to publish books in the spoken language of the people. While paying great deal of attention to the development of schooling and education in general, Metropolitan bishop H. Yakhymovych tried to fight two opposing social movements that seized schools and churches as well. These polar opposites were great affection to and subsequently influence from Polish Latinism and Russophilism, tendencies which found lots of followers among Greek-Catholics in the late 1860s - early 1870s.

Metropolitan bishop Spiridon Lavrynovych (elected in 1863) continued the course of $\mathrm{H}$. Yakhymovych, aimed at the further building of the network of public schooling, and making the idea of national identity of Ukrainians stronger. This case was largely contributed to by the so-called "Concordia", a declaration of inter-rite mutual understanding between Poles and Ukrainians in Galicia; it was approved by Pope Pius IX, the emperor, Latin and Ukrainian bishops, and it was in full operation until the collapse of the Austro-Hungarian Empire in 1918 and the emergence of two independent states, the Polish state and the Western Ukrainian People's Republic on its remnants. The main achievement of "Concordia" was the prohibition for Latin-Catholic Ukrainians and Greek-Catholic Ukrainians to switch/change their rite. In this way both rites in Galicia remained invariable in numbers, their territories were inviolable and their

165 Арсенич П. Греко-католицькі священики в національних змаганнях українців Галичини. Нова Зоря. 1991. Квітень. Ч. 5-6. 
identities were preserved. These all acted for the national and ecclesiastical interests of Ukrainian Galicia. It normalized publicchurch cooperation and relations inside the population of the region $^{166}$.

Traditions of the "Ruthenian Trinity" ("Ruska Triitsia") and of the "Spring of Nations" of 1848 were further strengthened in the Galician society by the intrigues of Polish government and church circles as well as by organized attacks and tangible successes of Russophilism in the $1860 \mathrm{~s}^{167}$. The Greek Catholic Church also gradually strengthened its position. Its main stronghold, the Eparchy of Lviv, had 1.3 million believers in most territories of Galicia and Bukovina. Another eparchy, Eparchy of Przemysl which belonged to the Halych Metropolis had 855,000 Greek Catholics ${ }^{168}$. About 1,200 priests worked tirelessly among the Galician peasantry ${ }^{169}$. Besides religion, literary works and arts contributed to the growth of the national and united identity of the Galicians, especially works of writers from the Dnieper region, in particular patriotic poetry of Taras Shevchenko. Gradually the center of the pan-Ukrainian national movement shifted to Galicia, and the region got the name "Ukrainian Piedmont".

Occupying a prominent place in the socio-cultural processes of the national movement, the patriotic clergymen tried to resist the assimilation processes and attempts to alienate rural culture from the urban. Metropolitan bishop Josyf Sembratovych (1870-1882) launched a large-scale struggle against immorality and drunkenness. Purposeful sermons in churches, missions on the periphery, an established network of fraternities in combination with active cultural and educational work produced tangible results, they improved reputation of the church and at the same time contributed to

166 Великий А. Г., ЧСВВ. 3 літопису християнської України. Т. VIII: XIX ст. Рим: Вид-во оо. Василіян, 1976. С. 154.

167 Аркуша О., Мудрий М. Русофільство в Галичині в середині XIX - на початку XX ст.: генеза, етапи розвитку, світогляд. Вісник Львівського університету. Серія історична. Вип. 34. Львів, 1999. С. 231-268; Турій О. Греко-католицька церква та українська національна ідентичність у Галичині. Ковчег. Ч. 4. Львів, 2003. С. 67-85.

168 Федорів Юрій, о. Історія церкви в Україні. Торонто, 1967. С. 311

169 Верига В. Нариси історії України (кінець XVIII - початок XX ст.). Львів: Світ, 1996. С. 200. 
the promotion of Christian morality and national upbringing. Despite the obstacles on the part of the Polish administration, Ukrainian schooling system was developing. This was largely facilitated by the school reform of the 1860s-1870s, having been carried out by the Austrian government under pressure from Ukrainian ambassadors and the Greek Catholic hierarchy. There was introduced compulsory primary education of children in their native language, so in the academic year 1869/1870, there were 1293 Ukrainian public elementary schools in operation, and by the end of the XIX century the amount of literate Ukrainians reached nearly $30 \%{ }^{170}$.

The progress of the national-cultural life was definitely marked and it was manifested by the foundation of the regional society "Prosvita" ("Enlightment"), which was the most popular organization in terms of amount of members. This scientific society was headed by the son of a Greek Catholic priest, Anatol' Vakhnyanyn (18411908), and the head was chosen in the course of the first meeting in Lviv, on December 8, 1868. The main task of "Prosvita" was to popularize adult education by means of publishing books and organizing a wide network of reading rooms in Ukrainian villages ${ }^{171}$. In 1912, it had 77 branches in Galicia, and its network could included 504 reading rooms and 2,664 libraries, hundreds of amateur art groups, which brought together about 200,000 members. According to the calculations of Lviv historian Volodymyr Pashuk back in 1914 "Prosvita" united 36,5 thousand members ${ }^{172}$. One of the characteristic features of the society "Prosvita" was that its peripheral branches and rural centers were mostly headed by priests.

Galician clergy took an active part in founding of a range of national societies and communities, which had to care about the wellbeing and welfare of citizens. They were two priests from village Olesko (near the town of Zolochiv), who founded the regional agricultural society "Rural Master" in 1899. Their names were Yulian

170 Стеблій Ф. Духовний П'ємонт українців. Львівщзина. Історико-культурні та краєзнавчі нариси. Львів: Центр Європи, 1998. С. 208-209.

171 Товариство «Просвіта» у Львові. Статути / Упор. В. Пашук. Львів, 1999. $272 \mathrm{c}$.

172 Пашук В. Товариство «Просвіта» у Львові. Львів. Історичні нариси. Львів: Інститут українознавства ім. І. Крип'якевича НАНУ, 1996. С. 245. 
and Toma Dutkevych and the aim of the organization was to protect peasants from the arbitrary rule. This organization stood on the forefront of the farmers' protection; it contributed to the educational and economic culture, as well as provided gardeners, farmers and beekeepers with necessary information ${ }^{173}$.

Readers of the region greatly appreciated literary and publicist works of the priests who were members of the "Prosvita" organization. The list of these popular authors included the names of Tyt Blonsky (1830-1897), Volodymyr Herasymovych (1870-1940), Ivan Hushalevych (1866-1934), Vasyl Zalozetskyi (1933-1915), Vasyl Il'nytskyi (1823-1895), Dmytro Yosyfovych (1867-1939), Bohdan Kyrchiv (1856-1900), Yurii Kmit (1872-1946), Mykhailo Petrushevych (1859-1895), Ivan Pleshkan (1866-1933) and others. ${ }^{174}$

There were also many talented composers among the clergymen. They were: Mykhailo Verbytsky (1819-1870), Porfyrii Bazhanskyi (1830-1920; the author of the opera "Dovbush"), Sydir Vorobkevych (1836-1903, Chernivtsi), Teofil' Bobrynskyi (1848-1882), Mykola Kumanovsky (1846-1924), Viktor Matiuk (1862-1902). There were also a lot of pedagogical workers, actors, ethnography scientists, librarians and museum workers ${ }^{175}$.

There were organized archeological and bibliographical exhibitions to celebrate the 900th anniversary of introduction of Christianity to Rus' and the 40th anniversary of the reign of Monarch Franz-Joseph. These events were organized with the great assistance and participation of church hierarchs and representatives of the Stauropegian Institute (which was established in 1788 in Lviv) ${ }^{176}$.

173 Злупко С. На чатах рідної землі: Євген Храпливий - учений, організатор, патріот. Львів: ЛНУ ім. І. Франка, 1999. С. 264-269.

174 Арсенич П. Греко-католицькі священики в національних змаганнях українців Галичини. Нова Зоря. 1991. Квітень. Ч. 5-6.

175 Загайкевич М. Михайло Вербицький: сторінки життя і творчості. Львів, 1998. 148 с.; Арсенич П. Греко-католицькі священики в національних змаганнях українців Галичини. Нова Зоря. 1991. Квітень. Ч. 5-6; Грабовецький В. Ілюстрована історія Прикарпаття. Вид. 2. Т. 3. Івано-Франківськ: Нова Зоря. C. 373-376.

176 Орлевич I.В. Діяльність Львівського Ставропігійського інституту (кінець XVIII - 60-i pp. XIX ст.). Автореф. дис. на здобуття наук. ступ, канд. іст. наук. Львів, 2000. 20 с.; Киричук О.С. Ставропігійський інститут у громадському житті Галичини (друга пол. ХІХ - поч. ХX ст.). Львів, 2001. 19 с. 
A year later, using the exhibits of the previous event as a basis, there was founded the Museum of the Stauropegian Institute, which had 60 manuscripts, 243 old printed books, 313 objects of church art presented $^{177}$.

The church leadership supported the scientific projects of the Shevchenko Scientific Society, in particular its Archaeographic Commission (it was founded in 1896 by Mykhailo Hrushevsky, and its vice-president was Ivan Franko), which launched a broad research program on the publication of "Acts to the Church Union". Thus, a series of articles on the history of the church appeared on the pages of the "Notes of the Shevchenko Scientific Society": about the life of village parishioners in Galicia in the 18th century (M. Zubrytsky), reviews on the printed pastoral messages of bishops of Lviv (I. Levytsky), and others ${ }^{178}$.

The Galician clergymen made a significant contribution to the Ukrainian cooperative movement. In 1883, Yevhen Dutkevych, a priest from Lviv, co-founded the "People's Trade Association", which spread its influence rather quickly and in a short time had its branches all over Galicia; soon afterwards there were hundreds of rural shops to work with it. Subsequently, rural dwellers created lots more cooperatives unions in their villages, in particular there was established a dairy cooperative union. Its creator was a priest from the Stryi region, Ostap Nizhankivsky. Soon, the dairy union, known in the Eastern Europe under the name "Maslosoiuz", was founded in the same county.

Timely creation of political institutions for civil society became another indication of the maturity of the community, of its active nationalization, as it proved positive politicization of the national movement. In 1890, a Rus'-Ukrainian Radical Party was formed in Lviv $^{179}$. Shortly afterwards there appeared the centrist Ukrainian

177 Скочиляс I. Дослідження візитаційної документації Львівської єпархії у Галичині в другій половині ХІХ - першій половині XX століть. Ковчег. Ч. 3. Львів, 2001. С. 470-489.

178 Ibid.

179 Нариси з історії суспільних рухів та політичних партій в Україні (XIX ХХ ст.). / за заг. ред. Я.Й. Малика. Львів: Світ, 2001. С. 23. 
National Democratic Party (1899) ${ }^{180}$ and the Ukrainian Social Democratic Party (1899), which was Marxist-leaning. With a noticeable assistance from Metropolitan bishop Sylvester Sembratovych the Ruthenian-Ukrainian Christian Union was formed in 1896 and it became a Ukrainian party of clerical nature. Soon after its creation, the Ukrainian National Democratic Party took the lead in the political movement of the region. It was the most powerful and influential one and defended the slogans of democratic nationalism, social reforms, as well as stood for political, economic and cultural independence, the division of Galicia into Polish (Western) and Ukrainian (Eastern), establishment of a national cultural autonomy within the Austrian-Hungarian state, but with the separate local parliament and administration.

There was one more organization closely connected with the Greek Catholic Church. It was the Catholic Union, and since 1911 it was reorganized into the right wing nationalistic Christian Social Party. This party was headed by a talented educator, historian and political figure Alexander Barvinsky (1847-1926) - ambassador of the Galician Diet and the Austrian Parliament, a full member of the Shevchenko Scientific Society, who was at the same time an editor of the party newspaper "Ruslan"181. He promoted the policy of the "new era", that is, understanding between Ukrainians and Poles in Galicia, and the possibility of national-political and cultural-economic development of both peoples under the auspices of the Austrian state $^{182}$.

The multi-vector process of the national movement in Galicia also included the wide-scale activity of the Order of St. Basil the Great. It is worth noting that after the Austrian government had banned to maintain relations with Rome, a lot of monasteries and monastic schools were closed, there was a restriction for the number people

\footnotetext{
180 Расевич В. Українська національно-демократична партія (1899-1918 рр.). Автореф. дис. на здобуття наук. ступ. канд. іст. наук. Львів, 1996. С. 17.

181 Аркуша О. Олександр Барвінський (до 150-річчя від дня народження). Львів, 1997; Олександр Барвінський. 1847-1927. Матеріали конференції, присвяченої 150 річниці від дня народження Олександра Барвінського. Львів, 2001.

182 Кугутяк М. Галичина. Сторінки історії. Івано-Франківськ, 1993. С. 64-74; Аркуша О. Галицький сейм: виборчі кампанії 1889 і 1895 pp. Львів, 1996. C. 11-36.
} 
who wanted to become monks, and monasteries became subordinate to local bishops, therefore the Order was in decline until the 1880's, with only 14 monasteries remaining in Galicia and 60 monks residing there $^{183}$. The renewed process of national revival in Galicia and the effective activity of the Greek Catholic Church prompted the leadership of the Order to make radical reforms. Supported by Metropolitan bishop Josyf Sembratovych of Galicia, the proto-abbot of the Galician province of Order of St. Basil the Great Rev.Fr. K. Sarnytskyy sent to Pope Leo XIII the draft of a reform, and it was approved by the Vatican. Subsequently there came the Apostolic Letter to Lviv (dated from May 12, 1882) with a "Special Protection" outlining the reform program for the Order. According to the program, the Order of St.Basil the Great was subordinated to Rome directly, and the Order of Jesuits was supposed to see the implementation of the Letter through. The main tasks of the Order could be listed as follows: to promote and strengthen the unity of Galicia's Ukrainians with the Holy See and the Catholic faith; to take part in education and religious education of the Ukrainian people, in particular youth; to continue education and training of highly educated, devoted to church and people priests, pastors, figures of the church hierarchy ${ }^{184}$. The reformation process started with the opening of the novitiate in Dobromyl, where new students studied all year long, afterwards they studied philosophy, theology, rhetoric in the monasteries of Galicia for three years, and thus they could become priests.

The Galician public and the Greek Catholic clergy watched the reformation of the Order of the Basilians without enthusiasm, as they believed that the Jesuits would definitely denationalize it. As a result, the reform was delayed until 1911. However, the reformation proved to be effective, it saved the Order and the Greek Catholic Church received many outstanding members. In 1888 the future Metropolitan

183 Ваврик М., ЧСВВ. Нарис розвитку і стану Василіанського Чина. XVII ХХ ст. Рим, 1979. С. 52-53.

184 Апостольський лист Папи Лева XIII «Про реформу Чину св. Василія Великого Української нації в Галичині». Записки ЧСВВ. С. 2. Т. 11. Рим, 1982. C. 351 . 
bishop Andrey Sheptytsky joined its ranks as a future monk ${ }^{185}$. The monks of the Order of St. Basil launched extensive apostolic work in Galicia: during 1889-1893 they carried out about 200 missions, mostly in villages. They founded religious communities and organizations popular among Galicians, and then worked there with great results. The Apostleship of Prayer had about 500,000 members, the Marian Wives amounted to 25,000. On the eve of World War I, 16 Basilian monasteries with 211 monks and 23 novices were operating in the country ${ }^{186}$.

Moral and religious education in the region as well as raising the national consciousness of the Galician people greatly relied on the publishing activity of the Basilian Order ${ }^{187}$. The main center of the Basilian Order' book publishing was the town of Zhovkva, there, in the summer of 1895, a large printing house was built at the monastery, and in 1898 they already had their own publishing house. Among the co-founders of the latter, there was the abbot of the Basilian monastery of St. Onuphrius, Andrey Sheptytsky. At the end of the XIX century, the order of the Basilians used to publish two dozen books annually, the number of copies of some of them reached 10-12 thousands, while the monthly edition "Missioner" ("The Missionary"), published since May 1, 1897, had 20 thousand copies $^{188}$.

It is worth noting that the last decade of the XIX century was characterized by a large flow of Galician emigrants going over the ocean (about 80 thousand people). The next decade their number amounted to more than 224 thousand, and the majority of them were peasants. Under these circumstances, it was the Basilian Order, in

185 Патрило І. Нарис історії Галицької провінції ЧСВВ. Записки ЧСВВ. Т. II, секція 2. Рим, 1982. С. 67-68; Добромильська реформа і відродження Української церкви. Львів: Місіонер, 2003.

186 Ваврик М., ЧСВВ. Нарис розвитку і стану Василіанського Чина. XVII ХХ ст. Рим, 1979. С. 64-65; Історія релігії в Україні. Т. 4. Католицизм. Київ, 2001. C. 353-371.

187 Архів Святоонуфріївського монастиря Отців Василіан (Львів). Постуляційний фонд.

${ }^{188}$ ЦДІАУЛ. Ф. 684. Оп. 1. Спр. 1563. Арк. 70-93; Лозинський М. Видавнича діяльність Василіянського Чину в умовах Добромильської реформи і в сучасний період. Добромильська реформа $і$ відродження Української церкви. Львів: Місіонер, 2003. С. 146-151. 
particular from the Galician Province, which sent missionaries to the new Ukrainian settlements in Canada, the United States, Brazil and Argentina. At the beginning of the XX century, all of them united in two overseas missions (in Canada and Brazil consequently), and they were under the rule of Bishop S. Ortynsky, who left for the United States after some time ${ }^{189}$.

Among the other prominent people, it was Metropolitan bishop Sylvester Sembratovych (1885-1898), who greatly facilitated the successful development and activity of the Basilian Order (the Order of St. Basil the Great) in the Galician province. He promoted the concept of the Ukrainian nation as a confessional community, initiated reforms that had to bring the Greek Catholic Church closer to the Western traditions and to restore the union in the Dnieper region $^{190}$.

During the rule of Metropolitan bishop S. Sembratovych there happened two significant events in the life of the Greek Catholic Church. In 1885 the Stanislav Eparchy was finally established. Its first bishop was the rector of the Theological Seminary in Vienna, a prominent theologian and historian of the Ukrainian Church, Reverend Yulian Pelesh, the person who granted priesthood to Andrey Sheptytsky. His residence was in the restored Holy Resurrection Cathedral. During 1891-1896 he was the Bishop of Przemysl. Also Yulian Pelesh was the author of the two-volume "History of the Union of the Ukrainian Church with Rome" (1880). The second Stanislav Greek Catholic bishop was Y. Kuilovsky, who ruled from 1891 to 1899 . He was followed by A. Sheptytsky (from 1899 to 1901), then by H. Khomyshyn (from 1901 to 1945), and by Assistant Bishop J. Liatyshevsky in 1929-1945 ${ }^{191}$. In general, at the end of the XIX century, the Metropolis of Galicia had five eparchies on the territory of the Ukrainian lands, which belonged to AustrianHungarian state. They were: Lviv-Galicia-Kamenetsk, which was

189 Ваврик М., ЧСВВ. Нарис розвитку і стану Василіанського Чина. XVII XX ст. Рим, 1979. С. 64-65; Історія релігії в Україні. Т. 4. Католицизм. Київ, 2001. С. 67-68.

190 Чорновол I. Українська фракція Галицького крайового сейму 1861-1901. Львів, 2002. С. 258-259; Сухий О. Від русофільства до москвофільства. C. 176-352.

191 ЦДІАУЛ. Ф. 358. Оп. 2. Спр. 4. Арк. 1-7; Спр. 10. Арк. 1-2; Полєк В. Духовна освіта на Прикарпатті. Нова зоря. 1991. Листопад. Ч. 33-34. 
ruled over by the Metropolitan bishop with the help of the Assistant Bishop, Przemysl-Sambir-Sianotsk, Stanislav, Mukachevo-Uzhhorod and Presov.

The second notable event of the period was the Synod of Lviv which was held in September-October of 1891. Among the people who participated there were three bishops, 160 priests and a papal legate. This synod organized the ecclesiastical rule of law, the judiciary and the liturgy, assured faithfulness of the Greek Catholics to the Holy See. In general, it helped to revive national life in the church, religious and social-political spheres ${ }^{192}$.

After the Synod of 1891, the spiritual and socio-political life of Greek Catholics became more active. Due to the efforts of the church, there were founded various social and religious structures, which included the Missionary Community of St. Paul; The Saint Peter Community of Aid to the Poor Parishes; The Institute of St. Yoshaphat for youth education; charity organizations of the Servant Sisters, who took care of children and the senior people. The Catholic Ruthenian-Ukrainian Union, led by Olexandr Barvinsky, was of a great importance and published the popular magazine "Ruslan". These various and effective activities of the church, organized in particular by Metropolitan bishop Sylvester Sembratovych, were highly appreciated and praised by the Holy See. At the glorifying celebration of the 300th anniversary of the Union of Brest in Rome, Pope Leo XIII dedicated a speech to the Ukrainian Church and granted Metropolitan bishop S. Sembratovych the rank of a cardinal ${ }^{193}$.

The Greek Catholic Church reached the XX century with several significant achievements: the loss of leadership in the processes of political nation-building did not deprive it of the role of the ethnospiritual leader of the Catholics of the Eastern Rite in the regions of Galicia and Transcarpathia. The trials of previous centuries have demonstrated that the church and its parishes are ready to engage in liberation campaigns in order not only to gain national-cultural rights, but also to struggle for the statehood and unity of Ukraine.

\footnotetext{
192 Великий А. Г., ЧСВВ. 3 літопису християнської України. Т. VIII: XIX ст. Рим: Вид-во оо. Василіян, 1976. С. 245-248.

193 Пашук А. Українська церква і незалежність України. С. 222-223; Історія релігії в Україні. Т. 4. Католицизм. Київ, 2001. С. 353-371, 407.
} 